\title{
Increase in ovarian kallikrein activity during ovulation in the gonadotrophin-primed immature rat
}

\author{
L. L. Espey, N. Tanaka, V. Winn and H. Okamura
}

\author{
Department of Biology, Trinity University, San Antonio, Texas 78284, USA; and Department of \\ Obstetrics and Gynecology, Kumamoto University Medical School, Kumamoto 860, Japan
}

\begin{abstract}
Summary. The ovulatory process was initiated in 25-day-old rats by injecting them with hCG (10 i.u., s.c.) 2 days after the animals had been primed with PMSG (10 i.u., s.c.). At 2-h intervals after hCG, the ovaries were extracted and assayed for glandular kallikrein activity by using a chromogenic substrate (H-D-Val-Leu-Arg- $p$-nitroanilide) which exhibits optical density (at $405 \mathrm{~nm}$ ) upon hydrolysis. In 0-h control ovaries the activity was $12.5 \times 10^{-3}$ kallikrein units $(\mathrm{KU}) / \mathrm{mg}$ protein and it increased to a peak of $56.6 \times 10^{-3} \mathrm{KU} / \mathrm{mg}$ at $12 \mathrm{~h}$ after $\mathrm{hCG}$, when the follicles first began to rupture. The kallikrein activity was distinguishable from ovarian plasminogen activator activity on the basis of $\mathrm{pH}$ optima and response to trypsin inhibitor (SBTI). The activity was inhibited by a s.c. dose of indomethacin of $0.3 \mathrm{mg} / \mathrm{rat}$, or higher, and this dosage inhibited ovulation. The results suggest that kallikrein activity contributes to the degradation of Graafian follicles during ovulation in mammals.
\end{abstract}

Keywords: ovulation; kallikrein; plasminogen activator; indomethacin; rat

\section{Introduction}

Mammalian ovaries undergo inflammatory-like changes at the time of ovulation (Espey, 1980). Ovaries become hyperaemic (Tanaka et al., 1989), and there is a local increase in a number of agents that are known to mediate inflammation. Prostaglandins are especially well known for their role in ovulation (Orczyk \& Behrman, 1972; Espey et al., 1986b). There is also evidence that bradykinin is released in ovulatory follicles (Smith \& Perks, 1983; Espey et al., 1986a; Yoshimura et al., 1988). More recently, lipoxygenase activity and leukotrienes have been implicated in the process (Reich et al., 1985; Espey et al., 1989). In addition to these vasoactive substances, ovulatory follicles contain serine proteases that are characteristic of acute inflammatory reactions. Collagenolytic activity (Espey \& Coons, 1976; Curry et al., 1985) and plasminogen activator (PA) activity (Strickland \& Beers, 1976; Espey et al., 1985) are the two proteases which have received the most attention.

In view of this growing evidence that the ovulatory process resembles an inflammatory reaction, the purpose of the present study was to examine ovulatory tissues for still another serine protease, namely kallikrein (EC 3.4.21.8), which is commonly involved in inflammation (Solomkin \& Simmons, 1983; Marceau et al., 1983).

\section{Materials and Methods}

Ovulation induction. Wistar rats were bred in our own animal facility and housed under a 14-h daily light cycle which began at $07: 00 \mathrm{~h}$. The young females in the litters were weaned at approximately 22 days of age and were distributed equally by weight $(40-50 \mathrm{~g})$ into the different experimental groups. At $08: 00 \mathrm{~h}$ on the day after weaning, the immature rats were injected s.c. with 10 i.u. PMSG (G-4877, Sigma Chemical Co., St Louis, MO, USA). At 08:00 h 2 days 
later, the ovulatory process was initiated by a s.c. injection of $10 \mathrm{i} . \mathrm{u}$. hCG (CG-5, Sigma Chemical Co.). The animals began ovulating $10-12 \mathrm{~h}$ later.

Inhibitor administration. Indomethacin (I-7378, Sigma Chemical Co.) was dissolved in distilled water containing $4 \mathrm{mg} \mathrm{Na}_{2} \mathrm{CO}_{3}$ for every $10 \mathrm{mg}$ indomethacin. The $\mathrm{pH}$ of the solution was adjusted to 7.4 by adding $0.1 \mathrm{~N}-\mathrm{HCl}$ during vigorous stirring. The indicated amounts of indomethacin were administered s.c. at $1 \mathrm{~h}$ before the animals were given hCG to induce the ovulatory process. Subsequently, the ovaries were removed at $12 \mathrm{~h}$ after hCG administration for assay. Trypsin inhibitor (SBTI; T-9003, Sigma Chemical Co.) was not injected into the animals, but was added to the final assay mixtures for kallikrein and PA at concentrations of 5 and $500 \mu \mathrm{g} / \mathrm{ml}$.

Ovulation determination. The animals were killed by cranial impaction at the designated intervals, and both ovaries were extirpated. The oviducts were separated from the ovaries and examined under a dissecting microscope with substage illumination. The numbers of ova were counted in each pair of oviducts to calculate the ovulation rate per rat.

Ovary extraction. The ovaries were cut free from the mesovarian ligament and blotted on a paper towel to remove blood from the surface. One ovary from each animal was placed in $1.0 \mathrm{ml}$ ice-cold $0.05 \mathrm{M}$-Tris buffer at pH 7.4 for kallikrein assay and $\mathrm{pH} 8.0$ for PA assay (except for the different $\mathrm{pH}$ values designated in the experiment on optimum $\mathrm{pH}$ ). The ovaries were homogenized for $30 \mathrm{sec}$ in a glass/glass homogenizer (S62 pestle and S73 tube, Tri-R Instruments, Inc., Rockville Center, NY, USA) connected to a stirrer (S63, Tri-R Instruments, Inc.) set at medium speed $(\sim 5000 \mathrm{rev} . / \mathrm{min})$. The homogenates were centrifuged routinely at $10000 \mathrm{~g}$ for $20 \mathrm{~min}$, at $4^{\circ} \mathrm{C}$, and the supernatant fluids were transferred to a polyethylene tube, capped, and stored at $-20^{\circ} \mathrm{C}$ until a complete series of experimental samples could be assayed simultaneously. (The procedure required $\sim 10 \mathrm{~min}$ from the time the animals were killed to the time the ovarian homogenates were placed in the refrigerated centrifuge.) Aliquants of the samples were assayed for protein content (Lowry reagent kit; P-5656, Sigma Chemical Co.) to express the enzyme activity per mg protein.

Kallikrein assay. The kallikrein substrate was a chromogenic peptide (S-2266; H-D-Val-Leu-Arg-p-nitroanilide dihydrochloride, KABIVITRUM, Stockholm, Sweden, distributed by Helena Laboratories, Beaumont, TX, USA) which has been used to measure glandular kallikrein in pancreas, urine and saliva, but which is not effective for plasma kallikrein (Amundsen et al., 1979). The method for the determination of activity is based on the optical density (at $405 \mathrm{~nm}$ ) that is generated by the enzymic release of $p$-nitroanilide (pNA) from the original substrate. The assay solution consisted of: (1) $800 \mu \mathrm{l} 0.05 \mathrm{M}$-Tris buffer, $\mathrm{pH} \mathrm{7.4;} \mathrm{(2)} 100 \mu \mathrm{l}$ of a $2.0 \mathrm{~mm}$ solution of S-2266 substrate in distilled water; and (3) $100 \mu$ l ovarian extract, or kallikrein standard. Standard curves were based on the hydrolysis of substrate by known kallikrein units (KU) of pig pancreatic kallikrein (K-3627, Sigma Chemical Co.). The mixtures were incubated in a shaker bath at $37^{\circ} \mathrm{C}$ for $90 \mathrm{~min}$. The reaction was stopped by adding $1.0 \mathrm{ml} 25 \%$ glacial acetic acid to each test tube. The absorbance (at $405 \mathrm{~nm}$ ) of the final reaction mixture was measured by a photometer (RESPONSE UV-VIS Spectrophotometer, Gilford Instruments Laboratories, Oberlin, OH, USA). In each experiment, the absorbance was also measured in blanks containing ovarian extract only, and these values were subtracted from the absorbance of the main assay solution in order to calculate the actual kallikrein activity in the ovarian samples. Following this procedure, the kallikrein activity was expressed as KU per mg protein in the extracts. The intra-assay coefficient of variation for this assay was $5 \cdot 6 \%$

$P A$ assay. The substrate for tissue PA activity was also a chromogenic peptide (S-2251; H-D-Val-Leu-Lys- $p$ NA; KABIVITRUM). The assay procedure was modified from a previous description (Espey et al., 1985) in that the assay solution consisted of: (1) $920 \mu \mathrm{l} 0.05 \mathrm{M}$-Tris buffer, $\mathrm{pH} 8.0$; (2) $40 \mu 13.8 \mathrm{~mm}$ solution of S-2251 substrate in distilled water; (3) $20 \mu \mathrm{l}$ of a plasminogen solution containing 10 casein units/ml distilled water; and (4) $20 \mu \mathrm{l}$ ovarian extract, or PA standard. Standard solutions were prepared from tissue PA extracted from human melanoma cell cultures (t-PA, KABIVITRUM). The PA activity was expressed in IU per mg protein in the extracts. The intra-assay coefficient of variation for this assay was $2 \cdot 1 \%$.

Statistical analysis. All data are presented as the mean \pm s.e.m. The significances of the differences among the means during the $24 \mathrm{~h}$ periovulatory period and in the indomethacin dose-response study were determined by Duncan's Multiple Range Test. The significances of the differences of the means of the SBTI groups were determined by the $t$ test for a difference between two independent means. The level of significance was taken as $P<0 \cdot 05$.

\section{Results}

\section{Onset of ovulation}

In the 8 animals that were used for the kallikrein assays at each test interval during ovulation (Fig. 1), all of the oviducts were examined for the presence of ova at the time the ovaries were extirpated. Ova first appeared at $10 \mathrm{~h}$ after hCG, with a total of only 5 ova present in the 9 pairs of oviducts, By $14 \mathrm{~h}$ after hCG, the oviducts contained $50.6 \pm 5.0 \mathrm{ova} / \mathrm{rat}$, and this increased to $72 \cdot 3 \pm 5 \cdot 3$ at $20 \mathrm{~h}$ after hCG. 


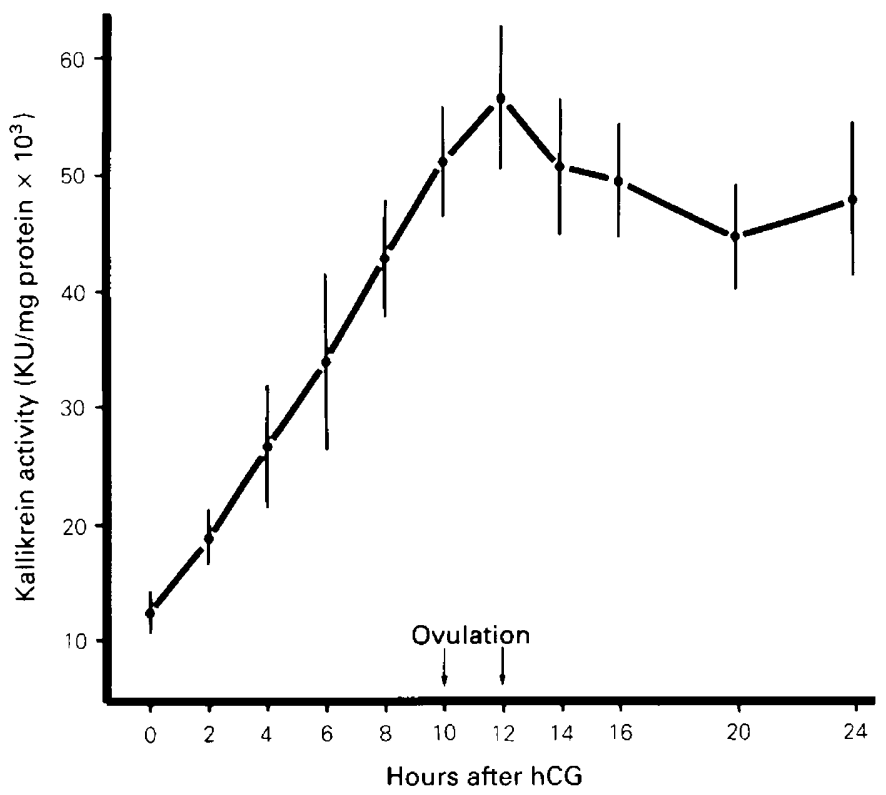

Fig. 1. Increase in ovarian kallikrein activity during the $24 \mathrm{~h}$ periovulatory period. Values are means \pm s.e. for 8 rats/group.

Increase in kallikrein activity during ovulation

Kallikrein activity was assayed simultaneously in ovaries from separate groups of 8 rats at 0,2 , $4,6,8,10,12,14,16,20$ and $24 \mathrm{~h}$ after the administration of hCG. The activity in the $0 \mathrm{~h}$ control ovaries was $12.5 \pm 1.9 \times 10^{-3} \mathrm{KU} / \mathrm{mg}$ protein, and increased $(P<0.01)$ to a peak of $56.6 \pm 6.3 \times 10^{-3}$ at $12 \mathrm{~h}$ after hCG when the ovarian follicles had just begun to rupture (Fig. 1).

\section{Dose-dependent inhibition of kallikrein activity by indomethacin}

Indomethacin was administered s.c. at $1 \mathrm{~h}$ before hCG in graded doses from $0.03 \mathrm{mg} / \mathrm{rat}$ to $10.0 \mathrm{mg} / \mathrm{rat}$ to groups of $8 \mathrm{rats}$ each. Subsequently, the ovaries were removed at $12 \mathrm{~h}$ after hCG and assayed for kallikrein activity. At a dose of $0.3 \mathrm{mg} / \mathrm{rat}$, indomethacin significantly reduced $(P<0.01)$ the normal amount of ovarian kallikrein activity at $12 \mathrm{~h}$ after hCG (Fig. 2$)$. The inibitory effect of indomethacin was not the consequence of any direct action on kallikrein activity because the addition of indomethacin to the assay solution in doses as high as $200 \mu \mathrm{g} / \mathrm{ml} \mathrm{did} \mathrm{not}$ significantly change the kallikrein activity in ovarian extracts. In 5 assays of pooled extracts of ovaries taken at $12 \mathrm{~h}$ after hCG, control samples had $0.138 \pm 0.003 \mathrm{KU} / \mathrm{ml}$ extract, while indomethacin-treated samples had $0 \cdot 134 \pm 0.004 \mathrm{KU} / \mathrm{ml}$ extract.

\section{Comparison of ovarian kallikrein activity with ovarian $P A$ activity}

Extracts from the ovaries of 6 additional rats (taken at $12 \mathrm{~h}$ after hCG administration) were pooled into one homogeneous solution, and aliquants were assayed for kallikrein or PA activity in triplicate at different $\mathrm{pH}$ values ranging from 6.8 to 8.6 . The results show that the optimum $\mathrm{pH}$ for kallikrein activity was at $\mathrm{pH} 7 \cdot 4$, and the optimum for PA activity was at $\mathrm{pH} 8 \cdot 0$ (Fig. 3).

For further comparison of kallikrein and PA activities, aliquants of individual ovarian extracts from 5 rats (killed at $12 \mathrm{~h}$ after hCG) were assayed for both enzymes in the presence of 5 or $500 \mu \mathrm{g}$ $\mathrm{SBTI} / \mathrm{ml}$ reaction mixture. The control level of $48.3 \pm 5.6 \times 10^{-3} \mathrm{KU} / \mathrm{mg}$ protein kallikrein 


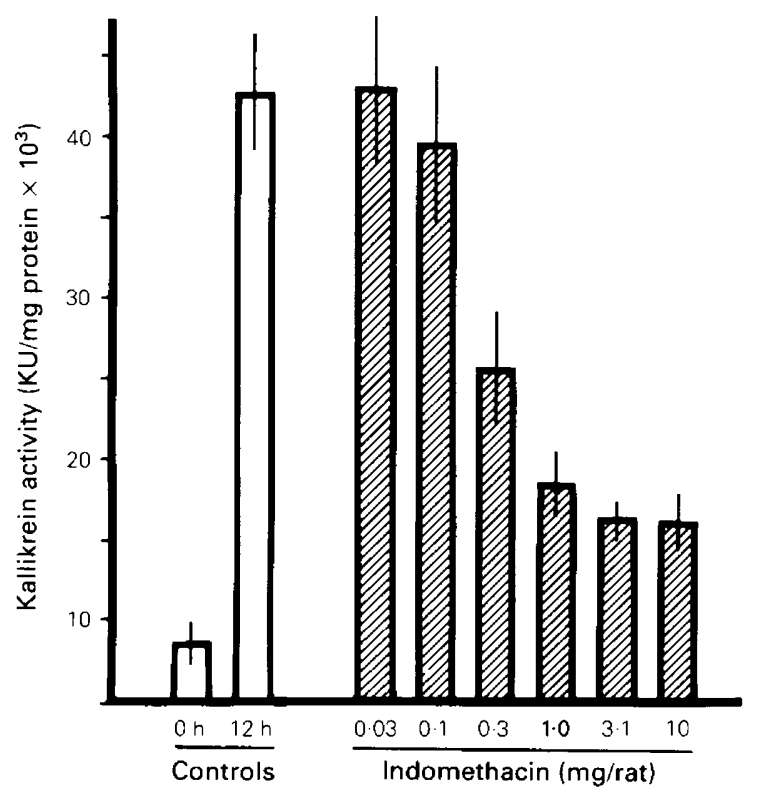

Fig. 2. Effect of s.c. injections of indomethacin on ovarian kallikrein activity at $12 \mathrm{~h}$ after hCG administration. Values are means \pm s.e. for 8 rats.

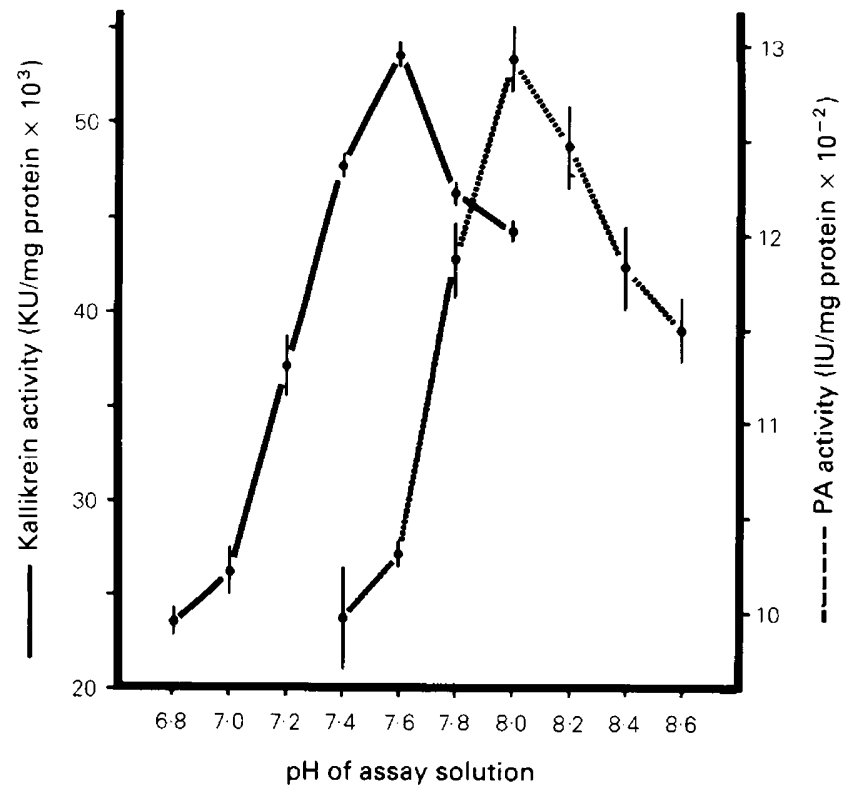

Fig. 3. Comparison of effect of $\mathrm{pH}$ on ovarian kallikrein activity versus ovarian PA activity. Values are means \pm s.e. for triplicate assays. 
activity decreased insignificantly to $40.9 \pm 3.7 \times 10^{-3}$ and $38.1 \pm 8.2 \times 10^{-3} \mathrm{KU} / \mathrm{mg}$ protein when mixed with 5 and $500 \mu \mathrm{g} / \mathrm{ml} \mathrm{SBTI}$, respectively. In contrast, the control level of $877 \pm 52 \mathrm{IU}$ PA activity $/ \mathrm{mg}$ protein decreased significantly $(P<0.001)$ to $185 \pm 48$ and $67 \pm 161 \mathrm{U} / \mathrm{mg}$ protein when mixed with 5 and $500 \mathrm{mg} / \mathrm{ml} \mathrm{SBTI}$, respectively.

\section{Discussion}

The present measurement of an increase in kallikrein-like activity in ovulating ovaries provides further support for the hypothesis that the biochemical events of ovulation resemble an acute inflammatory reaction. The results also indicate that enzymes like kallikrein might be contributing (along with collagenase and PA) to the proteolytic degradation of the connective tissue elements in ovulatory follicles. Collectively, the information suggests that ovulation may depend on the activation of a proteolytic 'cascade' comparable to the cascade of enzyme activity in inflammatory responses (Kaplan et al., 1981; Marceau et al., 1983).

Kallikreins are distinguished from other serine proteases by their ability to cleave specifically kallidin (lys-bradykinin) from kininogen (Fuller \& Funder, 1986). There are two types, plasma kallikrein and glandular kallikrein, with the latter being the subject of this study. Kallikreins are generated at sites of inflammation where abnormal surfaces activate Hageman factor, which cleaves pre-kallikrein to its active form (Solomkin \& Simmons, 1983; Marceau et al., 1983). The kallikreins then generate kallidin and kinins which lead to the vascular responses that are characteristic of inflamed tissues. Glandular kallikrein is inactivated within minutes after it is released into the circulation by binding to plasma protease inhibitors of the $\alpha_{1}$-antitrypsin and $\alpha_{2}$-macroglobulin type (Rabito et al., 1985).

The present data show that ovarian kallikrein activity is different from ovarian PA activity in at least two respects: (1) the pH optima for the two enzymes are different, and (2) SBTI has a greater inhibitory effect on PA activity. Regarding this latter difference, the results concur with a report that SBTI has little effect on glandular kallikrein activity from pancreatic and synovial tissues (Sharma et al., 1983), while it inhibits PA activity from fibroblasts (Quigley, 1979) and skeletal muscle cells (Festoff et al., 1982). In this respect ovarian PA activity is more like plasma kallikrein, which is also inhibited by SBTI (Sharma et al., 1983; Tans et al., 1987).

At doses of $0.3 \mathrm{mg} / \mathrm{rat}$ and higher, the cyclooxygenase inhibitor indomethacin reduced ovarian kallikrein activity. This suggests that the kallikrein activity might be dependent on ovarian prostanoid synthesis. However, indomethacin at doses of only 0.03 and $0.1 \mathrm{mg} /$ rat strongly inhibited ovarian prostaglandin synthesis (Espey et al., 1988, 1989) and yet these same doses did not significantly affect ovarian kallikrein activity. Furthermore, the low dose of $0.03 \mathrm{mg} / \mathrm{rat}$ did not inhibit ovulation, and $0.1 \mathrm{mg} / \mathrm{rat}$ only marginally reduced the number of ova that were released (Espey et $a l ., 1988,1989$ ). Therefore, on the basis of the responses to graded doses of indomethacin, it appears that the ovulation rate is more closely correlated to ovarian kallikrein activity than to ovarian PG levels. The results also suggest that indomethacin may reduce ovarian kallikrein activity by some mechanism other than cyclooxygenase inhibition.

One of the expected actions of ovarian kallikrein would be to generate kinins and cause local vasodilatation and greater vascular permeability (Marceau et al., 1983; Espey et al., 1986a). By this action, kallikrein might contribute to the ovarian hyperaemia which develops during ovulation (Tanaka et al., 1989). The kallikrein-kinin system is also known to activate phospholipase $\mathrm{A}_{2}$ and promote the synthesis of prostanoids (Sharma et al., 1983; Morita et al., 1984; Fuller \& Funder, 1986). Therefore ovarian kallikrein may be responsible, at least in part, for the well known increase in ovarian prostaglandins during ovulation.

Finally kallikrein is regulated by androgens in the submaxillary and prostate glands, by oestrogens in the anterior pituitary, and possibly by mineralocorticoids in the kidney (Fuller \& Funder, 1986). There is therefore circumstantial evidence to suggest that there may be a relationship between ovarian kallikrein activity and the well known changes in ovarian steroidogenic activity 
during ovulation. In any event, the present results suggest that glandular kallikrein contributes to the inflammatory-like changes which occur in ovulatory follicles of mammals.

This study was supported by the Lalor Foundation and by NIH Grant HD-21649. N.T. is a Post-Doctoral Fellow of the Lalor Foundation.

\section{References}

Amundsen, E., Putter, J., Friberger, P., Knos, M., Larsbraten M. \& Claeson, G. (1979) Methods of the determination of glandular kallikrein by means of a chromogenic tripeptide substrate. In Kinins II: Biochemistry, Pathophysiology and Clinical Aspects, pp. 83-95. Ed. M. Fujii. Plenum Publishing Corp., New York.

Curry, T.E., Jr, Dean, D.D., Woessner, J.F., Jr \& LeMaire, W.J. (1985) The extraction of a tissue collagenase associated with ovulation in the rat. Biol. Reprod. 33, 981-991.

Espey, L.L. (1980) Ovulation as an inflammatory reaction-A hypothesis. Biol. Reprod. 22, 73-106

Espey, L.L. \& Coons, P.J. (1976) Factors which influence ovulatory degradation of rabbit ovarian follicles. Biol. Reprod. 14, 233-245.

Espey, L.L., Shimada, H., Okamura, H. \& Mori, T. (1985) Effect of various agents on ovarian plasminogen activator activity during ovulation in pregnant mare's serum gonadotropin-primed immature rats. Biol. Reprod. 32, 1087-1094.

Espey, L.L., Miller, D.H. \& Margolius, H.S. (1986a) Ovarian increase in kinin-generating capacity in PMSG/hCG-primed immature rat. Am. J. Physiol. 251, E362-E365.

Espey, L.L., Norris, C. \& Saphire, D. (1986b) Effect of time and dose of indomethacin on follicular prosta+ glandins and ovulation in the rabbit. Endocrinology 119, 746-754.

Espey, L.L., Kohda, H., Mori, T. \& Okamura, H. (1988) Rat ovarian prostaglandin levels and ovulation as indicators of the strength of non-steroidal antiinflammatory drugs. Prostaglandins 36, 875-879.

Espey, L.L., Tanaka, N. \& Okamura, H. (1989) Increase in ovarian leukotrienes during hormonally-induced ovulation in the rat. Am. J. Physiol. 256, E753-E759.

Festoff, B.W., Patterson, M.R. \& Romstedt, K. (1982) Plasminogen activator: the major secreted neutral protease of cultured skeletal muscle cells. J. Cell. Physiol. 110, 190-195.

Fuller, P.J. \& Funder, J.W. (1986) The cellular physiology of glandular kallikrein. Kidney Int. 29, 953-964.

Kaplan, A.P., Ghebrehiwet, B., Silverberg, M. \& Sealey, J.E. (1981) The intrinsic coagulation-kinin pathway, complement cascades, plasma renin-angiotensin system, and their interrelationships. Critical Rev. Immunol. 3, 75-93.

Marceau, F., Lussher, A., Regoli, D \& Giroud, J.P. (1983) Pharmacology of kinins: their relevance to tissue injury and inflammation. Gen. Pharmacol. 14, 209-229.

Morita, I., Kanayasu, T. \& Murota, S.-I. (1984) Kallikrein stimulates prostacyclin production in bovine vascular endothelial cells. Biochim. Biophys. Acta 792, $304-309$.

Orczyk, G.P. \& Behrman, H.R. (1972) Ovulation blockade by aspirin or indomethacin-In vivo evidence for a role of prostaglandin in gonadotrophin secretion. Prostaglandins 1, 2-20.

Quigley, J.P. (1979) Phorbol ester-induced morphological changes in transformed chick fibroblasts: evidence for direct catalytic involvement of plasminogen activator. Cell 17, 131-141.

Rabito, S.F., Seto, M., Maitra, S.R. \& Carretero, O.A. (1985) Clearance and metabolism of glandular kallikrein in the rat. Am.J. Physiol. 248, E664-E668.

Reich, R., Kohen, F., Slager, R. \& Tsafriri, A. (1985) Ovarian lipoxygenase activity and its regulation by gonadotropin in the rat. Prostaglandins 30, 581-590.

Sharma, J.N., Zeitlin, I.J., Deodhar, S.D. \& Buchanan, W.W. (1983) Detection of kallikrein-like activity in inflamed synovial tissue. Arch. Int. Pharmacodyn. 262, $279-286$.

Smith, C. \& Perks, A.M. (1983) Changes in plasma kininogen levels in rats before ovulation, and after treatment with luteinizing hormone and oestradiol17ß. Acta endocr., Copenh. 104, 123-128.

Solomkin, J.S. \& Simmons, R.L. (1983) Cellular and subcellular mediators of acute inflammation. Surg. Clin. N. Am. 63, 225-243.

Strickland, S. \& Beers, W.H. (1976) Studies on the role of plasminogen activator in ovulation. J. biol. Chem. 251, 5694-5702.

Tanaka, N., Espey, L.L. \& Okamura, H. (1989) Increase in ovarian blood volume during ovulation in the gonadotropin-primed immature rat. Biol. Reprod. 40, 762-768.

Tans, G., Rosing, J., Berrettini, M., Lammle, B. \& Griffin, J.H. (1987) Autoactivation of human plasma prekallikrein. J. biol. Chem. 262, $11308-11314$.

Yoshimura, Y., Espey, L., Hosoi, Y., Adachi, T., Atlas, S.J., Ghodgaonkar, R.B., Dubin, N.H. \& Wallach, E.E. (1988) The effects of bradykinin on ovulation and prostaglandin production by the perfused rabbit ovary. Endocrinology 122, 2540-2546.

Received 25 January 1989 